This article is licensed under the Creative Commons Attribution-NonCommercial 4.0 International License (CC BY-NC) (http://www.karger.com/Services/OpenAccessLicense) Usage and distribution for commercial purposes requires written permission.

\title{
Various Endoscopic Features in Monomorphic Epitheliotropic Intestinal T-Cell Lymphoma
}

\author{
Yasuhiro Aoki ${ }^{a}$ Tomohisa Sujino ${ }^{a} \quad$ Kaoru Takabayashib \\ Makoto Mutakuchi $^{\mathrm{b}}$ Katsura Emoto ${ }^{c}$ Naoki Hosoe $^{\mathrm{b}}$ Haruhiko Ogata $^{\mathrm{b}}$ \\ Takanori Kanai ${ }^{a}$ \\ aDivision of Gastroenterology and Hepatology, Department of Internal Medicine, Keio \\ University School of Medicine, Tokyo, Japan; ${ }^{b}$ Center for Diagnostic and Therapeutic \\ Endoscopy, School of Medicine, Keio University, Tokyo, Japan; 'Division of Diagnostic \\ Pathology, Keio University School of Medicine, Tokyo, Japan
}

\section{Keywords}

Monomorphic epitheliotropic intestinal T-cell lymphoma · Small intestine · Gastrointestinal lymphoma Balloon endoscopy

\begin{abstract}
A 77-year-old female who had an acute severe abdominal pain was taken to the emergency room in the previous hospital. CT scans showed jejunum and ileum wall thickening and fatty deposits around the small intestinal tract, and gastrointestinal perforation could not be ruled out. By using single anal and oral balloon endoscopy, we observed mild edema with petechial erythema, shallow erosions with edematous mucosa and ulcers with surrounded disrupted villous structures at the jejunum and ileum. Histological analysis revealed atypical lymphocytes infiltrating the small intestinal mucosa demonstrating intraepithelial lymphocytosis. Immunohistochemical staining revealed that $C D 3, C D 7$, and CD56 staining was positive, and CD4, CD5, and CD8 staining was negative in infiltrated lymphocytes. We made the diagnosis of
\end{abstract}

Tomohisa Sujino
Division of Gastroenterology and Hepatology, Department of Internal Medicine
Keio University School of Medicine
35 Shinanomachi, Shinjuku-ku, Tokyo 160-8582 (Japan)
tsujino1224@keio.jp




\section{Case Reports in Gastroenterology}

Case Rep Gastroenterol 2021;15:312-322

DOI: $10.1159 / 000513902$

(c) 2021 The Author(s). Published by S. Karger AG, Basel www.karger.com/crg

Aoki et al.: Various Endoscopic Features in Monomorphic Epitheliotropic Intestinal T-Cell Lymphoma

monomorphic epitheliotropic intestinal T-cell lymphoma (MEITL) with the combination of HE staining and IHC. PET-CT showed abnormal uptake in irregular wall thickening of the small intestine, lymph nodes, ribs, spine and pelvic bone. She was treated with chemotherapy (etoposide, prednisolone, oncovin, cyclophosphamide, hydroxydaunorubicin) and is still alive 1 year after the diagnosis. We reported the various endoscopic findings in the same MEITL patient by using single balloon endoscopy. We also summarized endoscopic characteristics of MEITL patients.

(C) 2021 The Author(s)

Published by S. Karger AG, Basel

\section{Introduction}

Gastrointestinal malignant lymphomas often originate from B-cell. T-cell lymphoma in the gastrointestinal tract is rare. Compared with B-cell lymphoma, gastrointestinal T-cell lymphoma is difficult to diagnose at an early stage because it can be misdiagnosed as Crohn's disease or intestinal tuberculosis due to the inability to reach the endoscope for small bowel lesions. Although the development of balloon endoscopy has increased the detection and definitive diagnosis of intestinal $\mathrm{T}$ cell lymphoma, the endoscopic characteristics of the disease are still unknown. Enteropathy associated T-cell lymphoma (EATL) was formerly classified as type I, which is often associated with celiac disease, and type II, which is less commonly associated with the disease. In the 2017 WHO classification type I was defined as EATL and type II was newly reclassified as monomorphic epitheliotropic intestinal T-cell lymphoma (MEITL) [1]. The incidence of EATL in Asia is $1.9 \%$ of total lymphoma cases because celiac disease is not common in Asia [2]. MEITL is a T-cell lymphoma that forms an ulcerated mass mainly through the jejunum and ileum, with thickening of the surrounding mucosa. The histologic feature of EATL and MEITL is a large and polymorphic lymphoid cell accumulated in the intestine. EATL is composed of CD3, CD7 positive and CD4, CD8, CD56 negative cells. MEITL are CD3, CD7, CD8, and CD56 positive [2, 3]. The clinical course of MEITL is very aggressive with the intestinal obstruction and perforation, and its prognosis is generally poor [4]. Here, we report a case of MEITL expressed in a variety of endoscopic findings by using oral and anal balloon endoscopy and summarize the endoscopic features of MEITL.

\section{Case Presentation}

A 77-year-old female began feeling discomfort in her abdomen around the beginning of September 2019. She also developed night sweats and fever, with little improvement in symptoms. On September 30, she had acute severe abdominal pain and was taken to the emergency room in the previous hospital. On examination, the patient presented with a fever of 38 degrees, rebound pain in the lower abdomen, and muscular defenses. CT scans showed jejunum and ileum wall thickening. It showed fatty deposits around the small intestinal tract and thickening of the nearby intestinal wall, and gastrointestinal perforation could not be ruled out. CT

\section{Karger'=}




\section{Case Reports in Gastroenterology}

Case Rep Gastroenterol 2021;15:312-322

DOI: $10.1159 / 000513902$

(c) 2021 The Author(s). Published by S. Karger AG, Basel www.karger.com/crg

Aoki et al:: Various Endoscopic Features in Monomorphic Epitheliotropic Intestinal T-Cell Lymphoma

scans also showed adhesions due to inflammation of the sigmoid colon and small intestine (part of the ileum) (Fig. 1a, b). She was guided to our hospital for further investigation. The laboratory tests revealed a C-reactive protein (CRP) level of $6.80 \mathrm{mg} / \mathrm{dL}$ (normal range: 0 $0.14 \mathrm{mg} / \mathrm{dL}$ ) and an interleukin 2 receptor (IL2R) level of 3,652 (normal range: 121$613 \mathrm{U} / \mathrm{mL}$ ) (Table 1). Transanal small bowel balloon endoscopy revealed mild edema with petechial erythema, which was thought to be lymphatic follicular hyperplasia around $100 \mathrm{~cm}$ the oral side from the Bauhin valve. There were no abnormal findings in the colon. Biopsies were taken from the site of the suspected lymphatic follicle hyperplasia (Fig. 2a, b). Transoral small bowel balloon endoscopy revealed shallow erosions and edematous mucosa which were detected around $200 \mathrm{~cm}$ from the anal side at the vicinity of the Trites ligament. We found ulcers with surrounded disrupted villous structures around the anal side where erosion with edematous mucosa were noticed. We obtained one specimen from the erosion site and the other from the ulcer site (Fig. 2c, d). All specimen showed atypical lymphocytes infiltrating the small intestinal mucosa demonstrating intraepithelial lymphocytosis. Immunohistochemical staining showed that infiltrated lymphocytes were positive for CD3, CD7, and CD56, but negative for CD4, CD5, and CD8. EBER-ISH was negative (Fig. 3a-i). Although IHC represent CD8 was negative in the biopsy (finally positive in the resected tissue), we diagnosed our case was MEITL. PET-CT showed abnormal uptake in the irregular wall thickening of the small intestine and the mesenteric lymph nodes (Fig. 1c). Diffuse hyperaccumulation of the ribs, spine and pelvic bone (SUVmax: 8.30) was also observed, but there were no findings in bone marrow aspiration. The patient was diagnosed as MEITL in Lugano stage IV and started on a chemotherapy regimen of EPOCH (etoposide, prednisolone, oncovin, cyclophosphamide, hydroxydaunorubicin). She has been on chemotherapy for about 6 months and is still alive.

\section{Discussion}

MEITL is difficult to diagnose at an early stage compared to gastrointestinal B-cell lymphoma. Due to its high malignancy, MEITL is often associated with intestinal obstruction and perforation with a poor prognosis. Currently, the mean overall survival time of MEITL is 14.8 months (range, 2.4-27.2 months) [5], patients in the early stages have a significantly better prognosis than those in the advanced stages. Although reports of MEITL are rare, the number of reported cases is increasing because of the widespread use of balloon endoscopy. MEITL occupies the entire gastrointestinal tract, from the esophagus to the rectum, and is most commonly found in the small intestine. Yi et al. [5] collected 42 cases of MEITL, they reported 21 $(50 \%)$ cases in the jejunum and 19 (45\%) cases in the ileum. They also reported that multiple lesions were found in $36 \%$ of MEITL cases [5]. Previous reports did not mention the endoscopic features of the multiple lesions in MEITL. We summarized the clinical and endoscopic features in MEITL.

We analyzed 47 cases, 84 lesions (including this case) with endoscopic findings (Table 2) [6-35]. The mean age of the patients was 58.5 years and more than half of the cases (32 cases, $68.1 \%$ ) were male. Clinical symptoms were often diarrhea (31 cases, $66.0 \%$ ) and abdominal pain (16 cases, $34.0 \%)$. Twenty-three lesions (27.7\%) were in the jejunum, and 17 lesions 


\section{Case Reports in Gastroenterology}

\begin{tabular}{l|l}
\hline Case Rep Gastroenterol 2021;15:312-322 \\
\hline DOI: 10.1159/000513902 & $\begin{array}{l}\text { @ 2021 The Author(s). Published by S. Karger AG, Basel } \\
\text { www.karger.com/crg }\end{array}$ \\
\hline
\end{tabular}

Aoki et al.: Various Endoscopic Features in Monomorphic Epitheliotropic Intestinal T-Cell Lymphoma

$(20.5 \%)$ were in the ileum. Twenty-eight lesions $(33.7 \%)$ expressed ulcers, and 20 lesions (24.1\%) expressed mucosal edema. The shape of the ulcers varied from map-shaped to longitudinal. Seven lesions (8.4\%) expressed mucosal thickness, and 8 lesions (9.6\%) expressed mass formation. In our case, reddish lesions were found in the transanal endoscopy, and circular shallow ulcer covered with whitish edematous mucosa was detected by using transoral endoscopy. It also shows that edematous lesions and reddish lesions (granular mucosa) are characteristic of the early stage change of MEITL. Endoscopic finding of the small intestine revealed multiple circumferential or semicircumferential shallow ulcerations covered with whitish edematous mucosa. When the ulcer surrounds the lumen of the small intestine, it will lead to intestinal obstruction. Hong et al. [24] reported that the surrounding mucosa was edematous and thickened by countless fine granularities, showing mosaic mucosal pattern or velvety mucosa.

Although MEITL express a variety of endoscopic findings in the small intestine, ulcers, edematous mucosa, and mucosal thickening were reported in the colon. Shallow ulcerations with superficial exudates throughout the colon with loss of vascular pattern of MEITL was misdiagnosed as ulcerative colitis [32]. In our case, no lesions were found in the colon. Furthermore, colonoscopy findings are less characteristic of MEITL, so it is important to observe not only the colon but also the small intestine. Ishibashi et al. [28] searched the entire gastrointestinal tract in four cases of MEITL and demonstrates that MEITL can expand discontinuously into the mucosa along the entire course of the gastrointestinal tract. They reported that enteropathy-like lesions in the duodenum and small intestine, and microscopic (lymphocytic) proctocolitis with increased T-IELs lesions in the colon, are both important clinicopathological features for the early detection and diagnosis of MEITL. Their study suggests the importance of performing a random biopsy of the entire gastrointestinal tract to identify the initial lesions and spread of MEITL [28].

One of the reasons for the late diagnosis of MEITL is probably mainly due to its development in the small intestine. If the patient has unexplained abdominal pain and intestinal wall thickening, MEITL should be one of the differential diagnosis. When clinically MEITL is suspected, the entire gastrointestinal tract should be searched and a small intestinal balloon endoscopy should be performed. MEITL has a poor prognosis and early diagnosis and prompt treatment are required. Here, by using both oral and anal balloon endoscopy, we reported the various endoscopic findings of MEITL which occurred in the same patient. Balloon endoscopy was able to detect the early phase of MEITL, so the fact that a variety of endoscopic findings can be found even in the same patient is important.

\section{Statement of Ethics}

Written informed consent was obtained from the patient to publish this case. There were no ethics violations in the writing of this article.

\section{Karger'=}




\section{Case Reports in Gastroenterology}

Case Rep Gastroenterol 2021;15:312-322
(C) 2021 The Author(s). Published by S. Karger AG, Basel www.karger.com/crg

Aoki et al.: Various Endoscopic Features in Monomorphic Epitheliotropic Intestinal T-Cell Lymphoma

\section{Conflict of Interest Statement}

Takanori Kanai received a research grant from Miyarisan, Ezaki Glico and received honoraria for writing promotional material for Tanabemitsubishi pharm, Miyarisan, Takeda, Myran, EA Pharm, Abbvie; Haruhiko Ogata received honoraria for writing promotional material for Mochida, Takeda, Myran, EA Pharm.

\section{Funding Sources}

The authors have no funding sources to declare for this article.

\section{Author Contributions}

Yasuhiro Aoki and Tomohisa Sujino wrote the manuscript and the other authors provided critical feedback and helped in editing the manuscript.

\section{References}

1 Swerdlow SH, Campo E, Pileri SA, Harris NL, Stein H, Siebert R, et al. The 2016 revision of the World Health Organization classification of lymphoid neoplasms. Blood;127(20):2375-90.

2 Delabie J, Holte H, Vose JM, Ullrich F, Jaffe ES, Savage KJ, et al. Enteropathy-associated T-cell lymphoma: clinical and histological findings from the international peripheral T-cell lymphoma project. Blood. 2011 Jul;118(1):148-55.

3 Chott A, Haedicke W, Mosberger I, Födinger M, Winkler K, Mannhalter C, et al. Most CD56+ intestinal lymphomas are CD8+CD5-T-cell lymphomas of monomorphic small to medium size histology. Am J Pathol. 1998 Nov;153(5):1483-90.

4 Gale J, Simmonds PD, Mead GM, Sweetenham JW, Wright DH. Enteropathy-type intestinal T-cell lymphoma: clinical features and treatment of 31 patients in a single center. J Clin Oncol. 2000 Feb;18(4):795-803.

5 Yi JH, Lee GW, Do YR, Jung HR, Hong JY, Yoon DH, et al. Multicenter retrospective analysis of the clinicopathologic features of monomorphic epitheliotropic intestinal T-cell lymphoma. Ann Hematol. 2019 Nov;98(11):2541-50.

6 Liong CC, Ravindran S, Gnana Kumar G, Chin EF, Koh PS, Chan WK. Enteropathy-associated T-cell lymphoma: an extremely rare cause of chronic diarrhoea. Med J Malaysia. 2016 Apr;71(2):88-90.

7 Read S, Grundy E. Allostatic load - a challenge to measure multisystem physiological dysregulation. NCRM Work Pap. 2012;(4):1-10.

8 Noh CK, Roh J, Lee KJ. Monomorphic epitheliotropic intestinal T cell lymphoma presenting in weblike feature. Gastrointest Endosc. 2019 Apr;89(4):891-2.

9 Lenti MV, Biagi F, Lucioni M, Di Sabatino A, Paulli M, Corazza GR. Two cases of monomorphic epitheliotropic intestinal T-cell lymphoma associated with coeliac disease. Scand J Gastroenterol. 2019 Aug;54(8):965-8.

10 Bae JY, Ko BM, Min SK, Lee JC, Lee GW, Yoon LY, et al. A case of enteropathy-type T-cell lymphoma diagnosed by small bowel enteroscopy: a perspective on imaging-enhanced endoscopy. Gut Liver. 2012 Oct;6(4):516-9.

11 Lu S, Zhou G, Chen M, Liu W, Zhao S. Monomorphic Epitheliotropic Intestinal T-cell Lymphoma of the Stomach: Two Case Reports and a Literature Review. Int J Surg Pathol. 2020. DOI: 10.1177/1066896920953906. Online ahead of print.

12 Kakugawa Y, Terasaka S, Watanabe T, Tanaka S, Taniguchi H, Saito Y. Enteropathy-associated T-cell lymphoma in small intestine detected by capsule endoscopy. Leuk Lymphoma. 2012 Aug;53(8):1623-4.

\section{Karger'=}




\section{Case Reports in Gastroenterology}

Case Rep Gastroenterol 2021:15:312-322

DOI: $10.1159 / 000513902$

(C) 2021 The Author(s). Published by S. Karger AG, Base www.karger.com/crg

Aoki et al.: Various Endoscopic Features in Monomorphic Epitheliotropic Intestinal T-Cell Lymphoma

13 Fisher A, Yousif E, Piper M. Truth lies below: A case report and literature review of typical appearing polyps yet with an atypical diagnosis. World J Gastrointest Endosc. 2019 Jan;11(1):54-60.

14 Song MJ, Park CS, Hwang HS, Suh CW, Yoon DH, Huh J. A Case of type II enteropathy-associated T-cell lymphoma with Epstein-Barr virus positivity. Korean J Pathol. 2014 Dec;48(6):426-9.

15 Liu Y, Li YH, Li J, Qian JM, Zhou WX, Luo YP. Monomorphic epitheliotropic intestinal T-cell lymphoma complicated by common variable immunodeficiency. Intest Res. 2017 Oct;15(4):546-7.

16 Zhao L, Yang Y, Zhang Y. Type II enteropathy-associated t-cell lymphoma: A case report and literature review. Niger J Clin Pract. 2018 Jun;21(6):812-5.

17 Jiao G, Zheng Z, Jiang K, Zhang J, Wang B. Enteropathy-associated T-cell lymphoma presenting with gastrointestinal tract symptoms: A report of two cases and review of diagnostic challenges and clinicopathological correlation. Oncol Lett. 2014 Jul;8(1):91-4.

18 Aiempanakit K, Amatawet C, Chiratikarnwong K, Auepemkiate S, Kayasut K, Suwiwat S, et al. Erythema multiforme-like cutaneous lesions in monomorphic epitheliotropic intestinal T-cell lymphoma: a rare case report. J Cutan Pathol. 2017 Feb;44(2):183-8.

19 Tang XF, Yang L, Duan S, Guo H, Guo QN. Intestinal T-cell and NK/T-cell lymphomas: A clinicopathological study of 27 Chinese patients. Ann Diagn Pathol. 2018 Dec;37:107-17.

20 Ikebe T, Miyazaki Y, Abe Y, Urakami K, Ohtsuka E, Saburi Y, et al. Successful treatment of refractory enteropathy-associated T-cell lymphoma using high-dose chemotherapy and autologous stem cell transplantation. Intern Med. 2010;49(19):2157-61.

21 Hashimoto R, Matsuda T. Gastrointestinal: endoscopic findings of monomorphic epitheliotropic intestinal Tcell lymphoma. J Gastroenterol Hepatol. 2019 Feb;34(2):311.

22 Kim JB, Kim SH, Cho YK, Ahn SB, Jo YJ, Park YS, et al. A case of colon perforation due to enteropathyassociated T-cell lymphoma. World J Gastroenterol. 2013 Mar;19(11):1841-4.

23 Komeda Y, Kashida H, Sakurai T, Kono M, Nagai T, Asakuma Y, et al. A Case of Type II EnteropathyAssociated T-Cell Lymphoma in a Patient With Ulcerative Colitis. Am J Gastroenterol. 2017 Jun;112(6):833.

24 Hong YS, Woo YS, Park G, Lee K, Kang SH, Lee HW, et al. Endoscopic findings of enteropathy-associated T-cell lymphoma type II: A case series. Gut Liver. 2016 Jan;10(1):147-51.

25 Sato Y, Ono M, Sagawa T, Takimoto R, Hirakawa M, Ohnuma H, et al. Endoscopic findings of enteropathy-type T-cell lymphoma by double-balloon enteroscopy and capsule endoscopy. Dig Endosc. 2010 Jul;22(3):243-5.

26 Suzuki Y, Minemura H, Tomita H, Saito M, Watanabe N, Umeda T, et al. Monomorphic Epitheliotropic Intestinal T-cell Lymphoma Involving the Lung and Brain: A Rare Case Study. Intern Med. 2020 Oct;59(20):2559-63.

27 Aoyama Y, Tsunemine H, Zushi Y, Maruoka H, Goto Y, Kodaka T, et al. Colonal monomorphic epitheliotropic intestinal T-cell lymphoma with novel phenotype of cytoplasmic CD3 expression. J Clin Exp Hematop. 2018 Jul;58(2):102-6.

28 Ishibashi H, Nimura S, Kayashima Y, Takamatsu Y, Aoyagi K, Harada N, et al. Multiple lesions of gastrointestinal tract invasion by monomorphic epitheliotropic intestinal T-cell lymphoma, accompanied by duodenal and intestinal enteropathy-like lesions and microscopic lymphocytic proctocolitis: a case series. Diagn Pathol. 2016 Jul;11(1):66.

29 Liu C, Feng L, Sun X. Monomorphic Epitheliotropic Intestinal T-Cell Lymphoma: A Rare Case of Diffuse Ulcers in the Intestine. Clin Gastroenterol Hepatol. 2020 Jul;S1542-3565(20)30972-1. doi: 10.1016/j.cgh.2020.07.011. Online ahead of print.

30 Liu Z, He L, Jiao Y, Wang H, Suo J. Type II enteropathy-associated T cell lymphoma in the duodenum: A rare case report. Medicine (Baltimore). 2020;99(23):e20050.

31 Gentille C, Qin Q, Barbieri A, Ravi PS, Iyer S. Use of PEG-asparaginase in monomorphic epitheliotropic intestinal T-cell lymphoma, a disease with diagnostic and therapeutic challenges. Ecancermedicalscience. 2017 Sep;11:771.

32 Tian S, Xiao SY, Chen Q, Liu H, Ping J. Monomorphic epitheliotropic intestinal T-cell lymphoma may mimic intestinal inflammatory disorders. Int J Immunopathol Pharmacol. 2019 Jan-Dec;33:2058738419829387.

33 Nozari N. Type II Enteropathy-Associated T-cell Lymphoma: A Rare Report from Iran. Middle East J Dig Dis. 2017 Jan;9(1):55-7.

34 Samuel R, Krill T, Merwat S. Monomorphic Epitheliotropic Intestinal T cell Lymphoma: a Rare Cause of Chronic Diarrhea. J Gastrointest Cancer. 2019 Dec;50(4):1051-4.

35 Chuah YY, Tashi T, Lee YY, Fu TY, Shih CA. Enteropathy-associated T-cell Lymphoma (EATL) with intracranial metastasis : a rare and dismal condition. Acta Gastroenterol Belg. 2020 Jan-Mar;83(1):77-80.

\section{Karger'=}




\section{Case Reports in Gastroenterology}

Case Rep Gastroenterol 2021;15:312-322
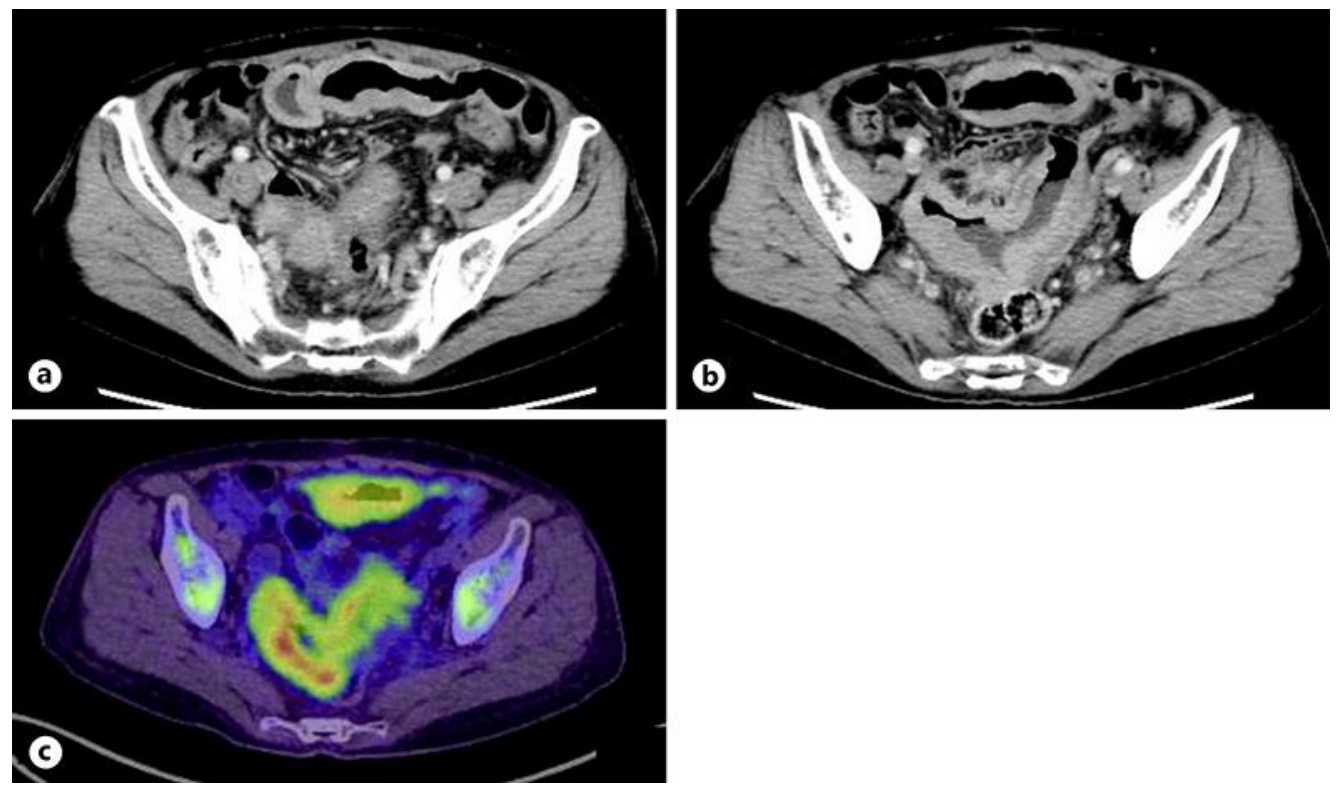

(C) 2021 The Author(s). Published by S. Karger AG, Basel (c) 2021 The Author(s).
www.karger.com/crg

Aoki et al.: Various Endoscopic Features in Monomorphic Epitheliotropic Intestinal T-Cell Lymphoma

Fig. 1. a, b CT scans showed jejunum and ileum wall thickening and fatty deposits around the small intestinal tract. They also showed adhesions of sigmoid colon and small intestine. c PET-CT showed abnormal uptake in irregular wall thickening of the small intestine and pelvic bone. 


\section{Case Reports in Gastroenterology}
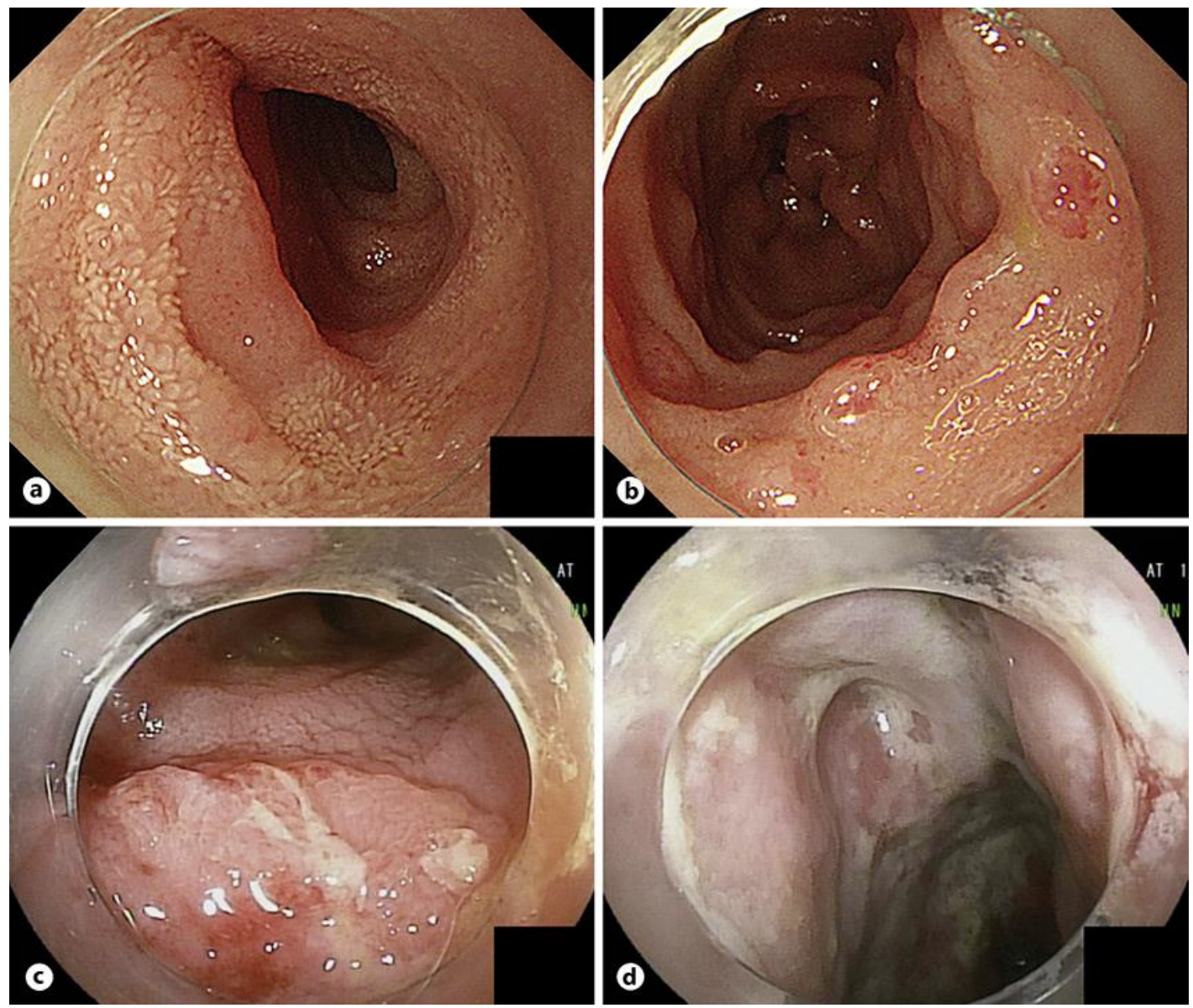

Fig. 2. a, b The structure of the small intestinal mucosa was preserved, and there was some lymphatic follicular hyperplasia. $\mathbf{c}, \mathbf{d}$ The villous structures were disrupted and the ulcer was covered with white moss.

\section{Karger's}




\section{Case Reports in Gastroenterology}

\begin{tabular}{l|l}
\hline Case Rep Gastroenterol 2021;15:312-322 \\
\hline DOI: 10.1159/000513902 & $\begin{array}{l}\text { ○ 2021 The Author(s). Published by S. Karger AG, Basel } \\
\text { www.karger.com/crg }\end{array}$ \\
\hline
\end{tabular}

Aoki et al:: Various Endoscopic Features in Monomorphic Epitheliotropic Intestinal T-Cell Lymphoma
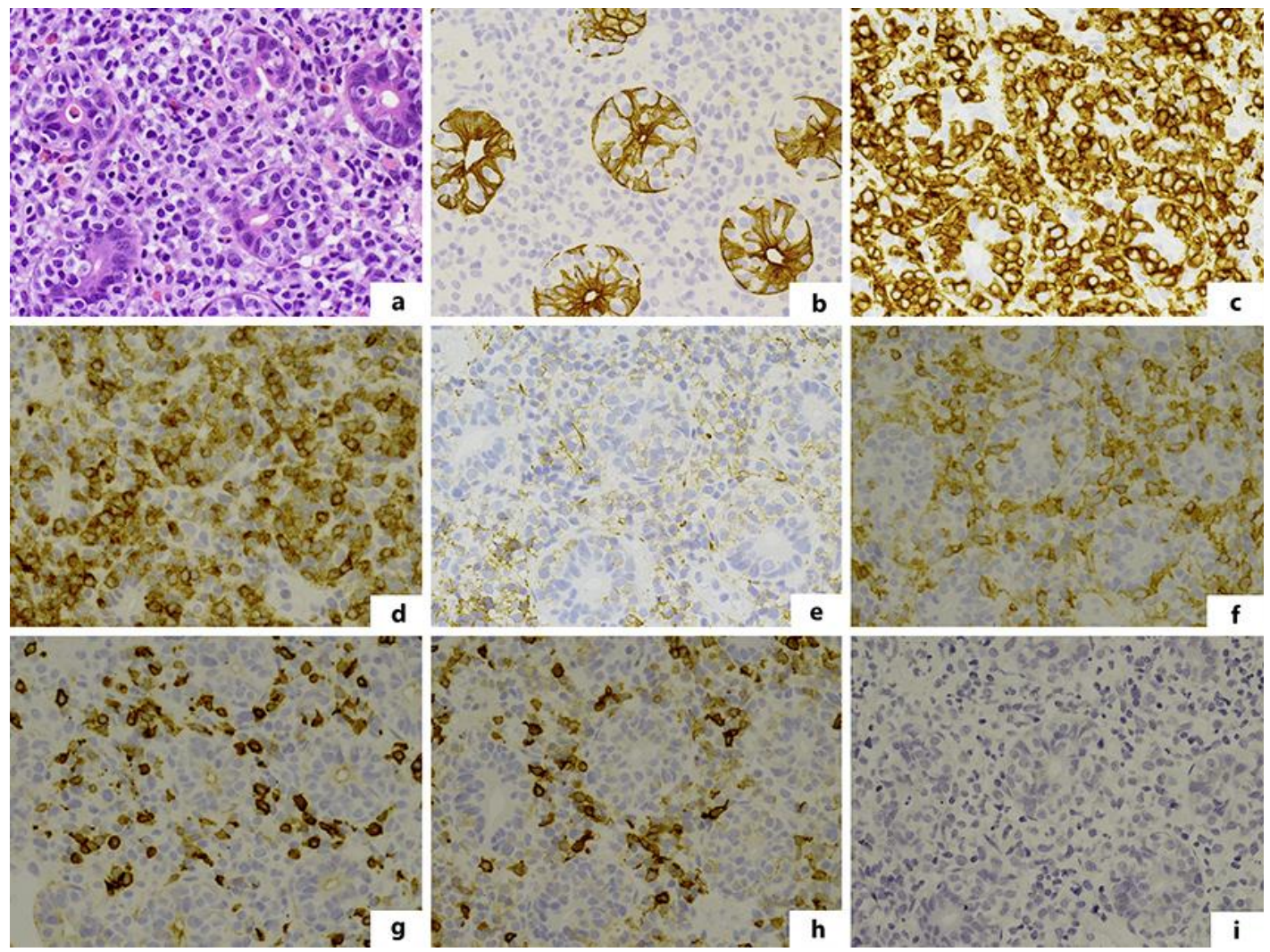

Fig. 3. Histological analysis showed atypical lymphocytes infiltration (a) (H\&E stain, $\times 400)$. Intraepithelial lymphocytosis was revealed by AE1/AE3 (b), ×400. Infiltrated lymphocytes were positive for CD3 (c), CD7 (d) and CD56 (e), but negative for CD4 (f), CD5 (g), CD8 (h), and EBER-ISH (i), $\times 400$. 
Case Reports in Gastroenterology
Case Rep Gastroenterol 2021;15:312-322

(c) 2021 The Author(s). Published by S. Karger AG, Basel www.karger.com/crg

Aoki et al.: Various Endoscopic Features in Monomorphic Epitheliotropic Intestinal T-Cell Lymphoma

Table 1. Laboratory test

\begin{tabular}{lrc}
\hline Test & Result & Reference range \\
\hline WBC $\left(\times 10^{9} / \mathrm{L}\right)$ & 13,400 & $3,300-8,600$ \\
Neutr (\%) & 42.3 & $40.0-75.0$ \\
Lympho (\%) & 50.4 & $18.0-49.0$ \\
Mono (\%) & 5.9 & $2.0-10.0$ \\
Eosino (\%) & 0.6 & $0.0-8.0$ \\
Baso (\%) & 0.8 & $0.0-2.0$ \\
RBC (×109/L) & 469 & $386-492$ \\
Hb (g/dL) & 12.5 & $11.6-14.8$ \\
Platelet (×109/L) & 35.2 & $15.8-34.8$ \\
AST (U/L) & 18 & $13-30$ \\
ALT (U/L) & 18 & $7-23$ \\
Alb (g/dL) & 2.6 & $4.1-5.1$ \\
CRP (mg/dL) & 6.80 & $0.00-0.14$ \\
BUN (mg/dL) & 15.4 & $8.0-20.0$ \\
Cre (mg/dL) & 0.76 & $0.46-0.79$ \\
IL2R (U/mL) & 3,652 & $121-613$ \\
\hline
\end{tabular}


Case Reports in Gastroenterology

\begin{tabular}{l|l}
\hline Case Rep Gastroenterol 2021;15:312-322 \\
\hline DOI: 10.1159/000513902 & $\begin{array}{l}\text { ○ 2021 The Author(s). Published by S. Karger AG, Basel } \\
\text { www.karger.com/crg }\end{array}$ \\
\hline
\end{tabular}

Aoki et al.: Various Endoscopic Features in Monomorphic Epitheliotropic Intestinal T-Cell Lymphoma

Table 2. Clinical features and endoscopic findings of MEITL 47cases

This case

\begin{tabular}{|c|c|c|c|}
\hline Age (years) & & $58.5 \pm 12.5$ & \\
\hline Sex (male:female) & & $32: 15$ & \\
\hline \multirow[t]{5}{*}{ Chief complains } & Diarrhea & $31(66.0 \%)$ & \\
\hline & Abdominal pain & $16(34.0 \%)$ & $※$ \\
\hline & Bloody stool & $6(12.8 \%)$ & \\
\hline & Weight loss & $9(19.1 \%)$ & \\
\hline & Nausea & $3(6.4 \%)$ & \\
\hline \multirow[t]{7}{*}{ Site } & Esophagus & $1(1.2 \%)$ & \\
\hline & Stomach & $3(3.6 \%)$ & \\
\hline & Duodenum & $18(21.7 \%)$ & \\
\hline & Small intestine & $40(48.2 \%)$ & $※$ \\
\hline & Jejunum & $23(27.7 \%)$ & $※$ \\
\hline & Ileum & 17 (20.5\%) & $※$ \\
\hline & Colon & $21(25.3 \%)$ & \\
\hline \multirow[t]{7}{*}{ Endoscopic finding } & Mucosal edema & $20(24.1 \%)$ & $※$ \\
\hline & Ulcer & $28(33.7 \%)$ & $※$ \\
\hline & Solitary ulcer & $7(8.4 \%)$ & $※$ \\
\hline & Multiple ulcers & $24(28.9 \%)$ & \\
\hline & Mass & $8(9.6 \%)$ & \\
\hline & Mucosal thickness & $7(8.4 \%)$ & $※$ \\
\hline & Stenosis & $3(3.6 \%)$ & \\
\hline
\end{tabular}

Values are presented as mean \pm SD or $n(\%)$. 